\title{
Changes in Marine Bacterial Populations in Ballast Water and Sediment of a LNG Carrier Bound for Qatar from Japan
}

\author{
Haruo MIMURA* Shuhei OKUYAMA** and Hiroshi ISHIDA***
}

\begin{abstract}
Changes in colony-forming eutrophic marine bacterial populations in a ship's ballast water and sediment were examined for 7 voyages in 2005 to 2006. In the ballast water taken in Japan, total numbers of colony-forming cells were highly variable in the range of $10^{3.1}$ to $10^{5.6}$ colony-forming units (CFU) $\mathrm{ml}^{-1}$ regardless of the season. The ballast water loaded in Japan was exchanged in the high seas in the Indian Ocean. During the exchange of ballast water, the values in the samples taken from discharging and reloading ballast water varied from $10^{3.2}$ to $10^{4.7} \mathrm{CFU} \mathrm{ml} l^{-1}$ and $10^{2.7}$ to $10^{5.2} \mathrm{CFU} \mathrm{ml}^{-1}$, respectively. When the reloaded ballast water was discharged at the Ras Laffan port in Qatar, the values varied from $10^{2.6}$ to $10^{5.1} \mathrm{CFU} \mathrm{ml}^{-1}$. These results indicate that the ballast water exchange in the high seas is not effective as for the reduction of marine bacterial populations in ballast water. In the samples of sediment, the values between $10^{5.2}$ and $10^{7.2} \mathrm{CFU} \mathrm{ml}{ }^{-1}$ were estimated for all seasons in which voyages took place, indicating the importance of management of sediment in ballast tanks as well as ballast water of ocean going vessels.

As for the numbers of Vibrio sp. cells, which made colonies on the selective agar plate at $20^{\circ} \mathrm{C}$, in the ballast water and sediment samples, the values varied from zero to $10^{5.4} \mathrm{CFU} \mathrm{ml}{ }^{-1}$, and so far examined, we did not detect pathogenic Vibrio cholerae, which can grow even at $37^{\circ} \mathrm{C}$, throughout all the seven voyages.
\end{abstract}

Keywords : ship's ballast water, sediment, colony-forming marine bacteria, Vibrio sp.

\section{Introduction}

The ballast water management of ocean going vessels is very important for the conservation of marine biodiversities and the diffusion prevention of the infectious diseases caused by pathogenic $\mathrm{Vi}$ brio cholerae invaded in a ship's ballast water ${ }^{(1)}$. The discharged ballast water at a foreign port seems to give some economical damage to the fish farming because a ship's ballast water is possibly contained some toxic dinoflagellates ${ }^{(2-4)}$.

The European zebra mussel, the European shore crab, the fishes of Round Goby and Ruffe, the tropical green algae, the Northern Pacific kelp, the Northern Pacific seastar, the American comb jelly, and the giant fan worm have been pointed out as another major invasive species by the International Maritime Organization (IMO) $)^{(5)}$. In those species, the European zebra mussel has spread most successfully ${ }^{(6)}$
We have previously examined ballast water and sediment in ballast tanks of a liquefied natural gas (LNG) carrier (110,000 gross tons) bound for Qatar from Japan for six voyages throughout 2002 to 2003 in relation to the changes in marine bacterial populations and pathogenic $V$. cholerae $^{(7)}$. Through the experiments, we found that the colony-forming marine bacterial populations were highly valuable in ballast water loaded on and discharged from the ship. Any of $V$. cholerae was not detected from all the samples.

In ballast tanks, some of marine bacteria could survive by making biofilm ${ }^{(8)}$ as well as in pooled ballast water and sediment on the bottom of ballast tanks ${ }^{(7)}$.

In this paper, changes in populations of colony-forming marine bacteria and pathogenic $V$. cholerae were examined in the LNG carrier's ballast water and sediment. In addition, we investigated the total number of temperature sensitive marine Vibrio species cells, which made colonies on the selective plate at

\footnotetext{
* Non-member, Graduate School of Maritime Sciences, Fukae, Kobe 658-0022, Japan, hmimura@maritime.kobe-u.ac.jp

** Student member, Graduate School of Maritime Sciences, Fukae, Kobe 658-0022, Japan

*** Member, Graduate School of Maritime Sciences, Fukae, Kobe 658-0022, Japan, h-ishida@maritime.kobe-u.ac.jp
} 
$20^{\circ} \mathrm{C}$, but not at $37^{\circ} \mathrm{C}$, in those samples.

\section{Materials and Methods}

\subsection{Navigation route of the LNG carrier}

The navigation route between Japan and Qatar is shown in Fig. 1. It takes approximately two weeks to go from a port in Japan to the Ras Laffan port in Qatar. The LNG carrier used in the experiments has one forward- and one after-peak ballast tanks and ten side ballast tanks located tandem on the starboard and port sides. Total capacity of the tanks is $55,000 \mathrm{~m}^{3}$.

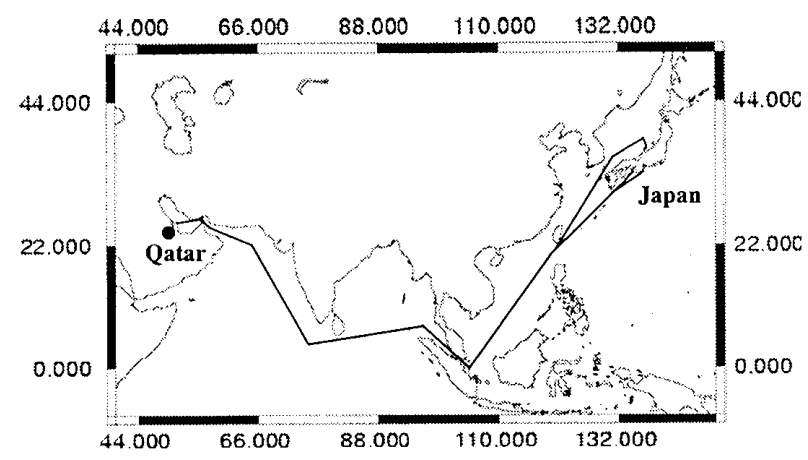

Fig. 1. Navigation route between Qatar and Japan.

\subsection{Sampling of ballast water and sediment on board}

Ballast water was loaded on the ship at four different local ports such as the Osaka port (twice), the Yokkaichi port (twice), the Niigata port (twice), and the Himeji port (once) before leaving for Qatar (Fig. 2). When ballast water was loaded aboard, it was sampled at given time.

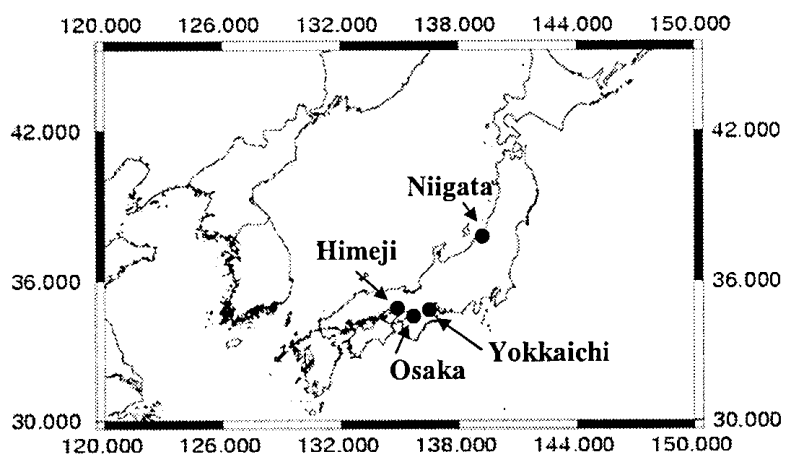

Fig. 2. The local ports where ballast water was loaded prior to leaving for Qatar.

After arriving in the high seas in the Indian Ocean, the ballast water, which had been taken at the original port, was discharged prior to re-loading ballast water (Fig. 3). The exchange of ballast water was continuously carried out for each ballast tank. The ballast

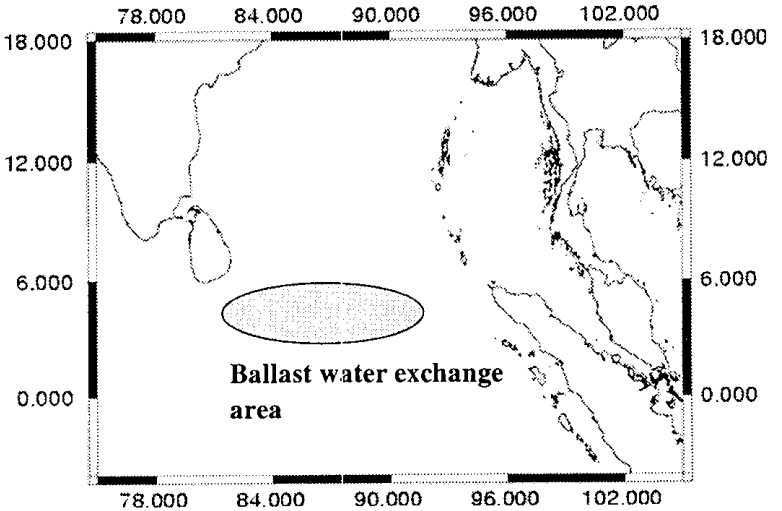

Fig. 3. Overview of ballast water exchange area in the high seas on the way to Qatar from Japan.

Table 1. Ballast water exchange sites in the high seas

\begin{tabular}{|c|c|}
\hline $\begin{array}{c}\text { Times of voyages and } \\
\text { sampling date }\end{array}$ & Ballast water exchange site \\
\hline \multirow[t]{2}{*}{ 1. January 26,2005} & $05-56 \mathrm{~N}, 089-06 \mathrm{E}$ (Discharging site) \\
\hline & $05-50 \mathrm{~N}, 087-16 \mathrm{E}$ (Reloading site) \\
\hline \multirow[t]{2}{*}{ 2. May 7, 2005} & 05-59N, 089-59E (Discharging site) \\
\hline & 05-59N, 089-34E (Reloading site) \\
\hline \multirow[t]{2}{*}{ 3. September 27,2005} & 05-34N, 091-59E (Discharging site) \\
\hline & $05-35 \mathrm{~N}, 091-28 \mathrm{E}$ (Reloading site) \\
\hline 4. October 31,2005 & $05-34 \mathrm{~N}, 089-36 \mathrm{E}$ (Discharging site) \\
\hline 4. November 1,2005 & $05-33 \mathrm{~N}, 084-48 \mathrm{E}$ (Reloading site) \\
\hline \multirow[t]{2}{*}{ 5. February 5, 2005} & $05-48 \mathrm{~N}, 092-58 \mathrm{E}$ (Discharging site) \\
\hline & $05-35 \mathrm{~N}, 091-52 \mathrm{E}$ (Reloading site) \\
\hline \multirow[t]{2}{*}{ 6. April 10, 2006} & $05-34 \mathrm{~N}, 089-46 \mathrm{E}$ (Discharging site) \\
\hline & 05-34N, 087-34E (Reloading site) \\
\hline \multirow[t]{2}{*}{ 7. August 17,2006} & $05-34 \mathrm{~N}, 083-34 \mathrm{E}$ (Discharging site) \\
\hline & $05-35 \mathrm{~N}, 082-45 \mathrm{E}$ (Reloading site) \\
\hline
\end{tabular}

water discharged from and re-loaded on the ship was sampled at given time.

It took approximately 10 days to reach the high seas in the Indian Ocean. The area was located in 5 degrees north and 82 - 93 degrees east. The exact site where the ballast water was exchanged for each voyage is shown in Table 1.

The IMO requires that ballast water be exchanged in the high seas, i.e., the open ocean at least 50 nautical miles from the nearest land and 200 meters in $\operatorname{depth}^{(9)}$.

The ballast water exchanged in the high seas was transported and discharged at the Ras Laffan port in Qatar. The ballast water discharged was sampled at given time.

Sampling of ballast water was carried out at the outlet of the ballast pump located in the engine room. After the sampled ballast water was poured into an 
autoclaved bottle $\left(250 \mathrm{ml}, \mathrm{NALGENE}^{\circledR}\right)$, it was stored in the refrigerator at $4^{\circ} \mathrm{C}$ until use.

On the return trip from Qatar to Japan, no ballast water was in the ballast tanks because LNG was fully loaded on board; therefore, sediment in ballast tanks was available to sample. The samples of sediment, which were taken from several sites in a ballast tank, were placed into each autoclaved bottle $(250 \mathrm{ml}$, NALGENE ${ }^{\circledR}$ ) and kept at $4^{\circ} \mathrm{C}$ until use.

Seven to 10 days after departing Japan, a surface water and a middle-depth water at $6-8 \mathrm{~m}$ from the surface of the ballast water in a tank were sampled into a Van Dorn Water Sampler (5026, RIGOSHA\&Co., Ltd.) and then poured into the autoclaved bottle $\left(250 \mathrm{ml}\right.$, NALGENE $\left.{ }^{\circledR}\right)$. The samples thus obtained were stored at $4^{\circ} \mathrm{C}$ until use.

\subsection{Enumeration of colony-forming marine bac- teria in ballast water and sediment}

The samples, if necessary, were serially diluted with autoclaved natural seawater, and then the diluted sample $(0.1 \mathrm{ml})$ was spread onto the agar plates containing $5 \mathrm{~g}$ Bacto peptone (Difco, Michigan, USA), $1 \mathrm{~g}$ yeast extract (Difco, Michigan, USA), and $15 \mathrm{~g}$ agar per liter of natural seawater. Incubation was carried out at $20^{\circ} \mathrm{C}$ for 6 days, and colonies made on the plates were counted. The number of colony-forming cells was shown as colony-forming units (CFU) $\mathrm{ml}^{-1}$.

\subsection{Enumeration of colony-forming marine $V i$ - brio sp.}

A thiosulphate-citrate-bile salts-sucrose (TCBS) selective medium (Pearlcore TCBS Agar "Eiken," Eiken Chemical Co., Ltd.) was used for counting colony-forming marine Vibrio sp. The TCBS selective medium contained $10 \mathrm{~g}$ peptone, $5 \mathrm{~g}$ yeast extract, 20 $\mathrm{g}$ sucrose, $5 \mathrm{~g}$ bile powder, $3 \mathrm{~g}$ sodium cholate, $10 \mathrm{~g}$ $\mathrm{NaCl}, 10 \mathrm{~g}$ sodium citrate, $7 \mathrm{~g}$ sodium thiosulfate, $1 \mathrm{~g}$ iron (III) citrate, $0.04 \mathrm{~g}$ bromothymol blue, $0.04 \mathrm{~g}$ thymol blue, and $15 \mathrm{~g}$ agar per liter of distilled water, $\mathrm{pH}$ 8.2. After serial dilution with autoclaved natural seawater, if necessary, the sample $(0.1 \mathrm{ml})$ was spread onto TCBS selective agar plates, and incubation was carried out at $20^{\circ} \mathrm{C}$ for two days.

2.5 Identification of isolates that made yellow-colored colonies on TCBS selective agar plate

The isolates that made colonies on TCBS selective agar plates even at $37^{\circ} \mathrm{C}$ were identified based on their morphological, biochemical, and physiological properties. Identification based on the partial 16S rDNA sequences was also carried out for the isolates. It was performed at the National Collections of Industrial, Food, and Marine Bacteria Japan Co., Ltd. (Shimizu, Shizuoka). Briefly, a partial 16S rDNA gene fragment (about $500 \mathrm{bp}$ ) at 5 '- end was amplified by PCR with the MicroSeq ${ }^{(1)} 50016 \mathrm{~S}$ rDNA kit (Applied Biosystems Japan), and the amplified gene fragment was sequenced with a sequencer. Homology analysis was carried out by the use of sequencing data with Mi$\operatorname{croSeq}^{\circledR}$ Microbial Identification System Software and the database of MicroSeq ${ }^{\circledR}$ Bacterial 500 Library (Applied Biosystems, CA, USA) and GenBank/DDBJ/EMBL. When the partial rDNA sequence obtained from the isolate showed the homology percentage of less than $97 \%$ in comparison with those in database, it was deposited in GenBank/DDBJ/EMBL.

\section{Results and Discussion}

\subsection{Changes in colony-forming marine bacterial populations in ballast water loading and dis- charging aboard}

Ballast water was sampled when it was loaded aboard at an original port in Japan, discharged and re-loaded in the high seas in the Indian Ocean, and discharged at the Ras Laffan port in Qatar (Fig. 4). Regardless of the sampling time and season, variable numbers of colony-forming cells were observed.

As for the numbers of colony-forming cells in the samples taken at the original port in Japan, the values varied, and the minimum and the maximum values obtained were $10^{3.1} \mathrm{CFU} \mathrm{ml}^{-1}$ in September 2005 (Fig. $4 \mathrm{C}$, the third voyage) and $10^{5.6} \mathrm{CFU} \mathrm{ml}^{-1}$ in October 2005 (Fig. 4D, the fourth voyage), respectively, throughout all the voyages. When the ballast water, which had already been loaded in Japan, was discharged in the high seas, the value varied from $10^{3.2}$ $\mathrm{CFU} \mathrm{ml^{-1 }}$ in October 2005 (Fig. 4D, the fourth voyage) to $10^{4.7} \mathrm{CFU} \mathrm{ml}{ }^{-1}$ in August 2006 (Fig. 4G, the seventh voyage). After the ballast water was discharged, new ballast water was re-loaded in the high seas; the number of colony-forming cells varied from $10^{2.7} \mathrm{CFU} \mathrm{ml}^{-1}$ in February 2006 (Fig. 4E, the fifth voyage) to $10^{5.2} \mathrm{CFU} \mathrm{ml}{ }^{-1}$ in November 2005 (Fig. $4 \mathrm{D}$, the fourth voyage). At the Ras Laffan port, the reloaded ballast water was sampled at given time when it was discharged. Again, the value varied from $10^{2.6}$ $\mathrm{CFU} \mathrm{ml}{ }^{-1}$ in February 2006 (Fig. 4E, the fifth voyage) to $10^{5.1} \mathrm{CFU} \mathrm{m}{ }^{-1}$ in May 2005 (Fig. $4 \mathrm{~B}$, the second voyage). 

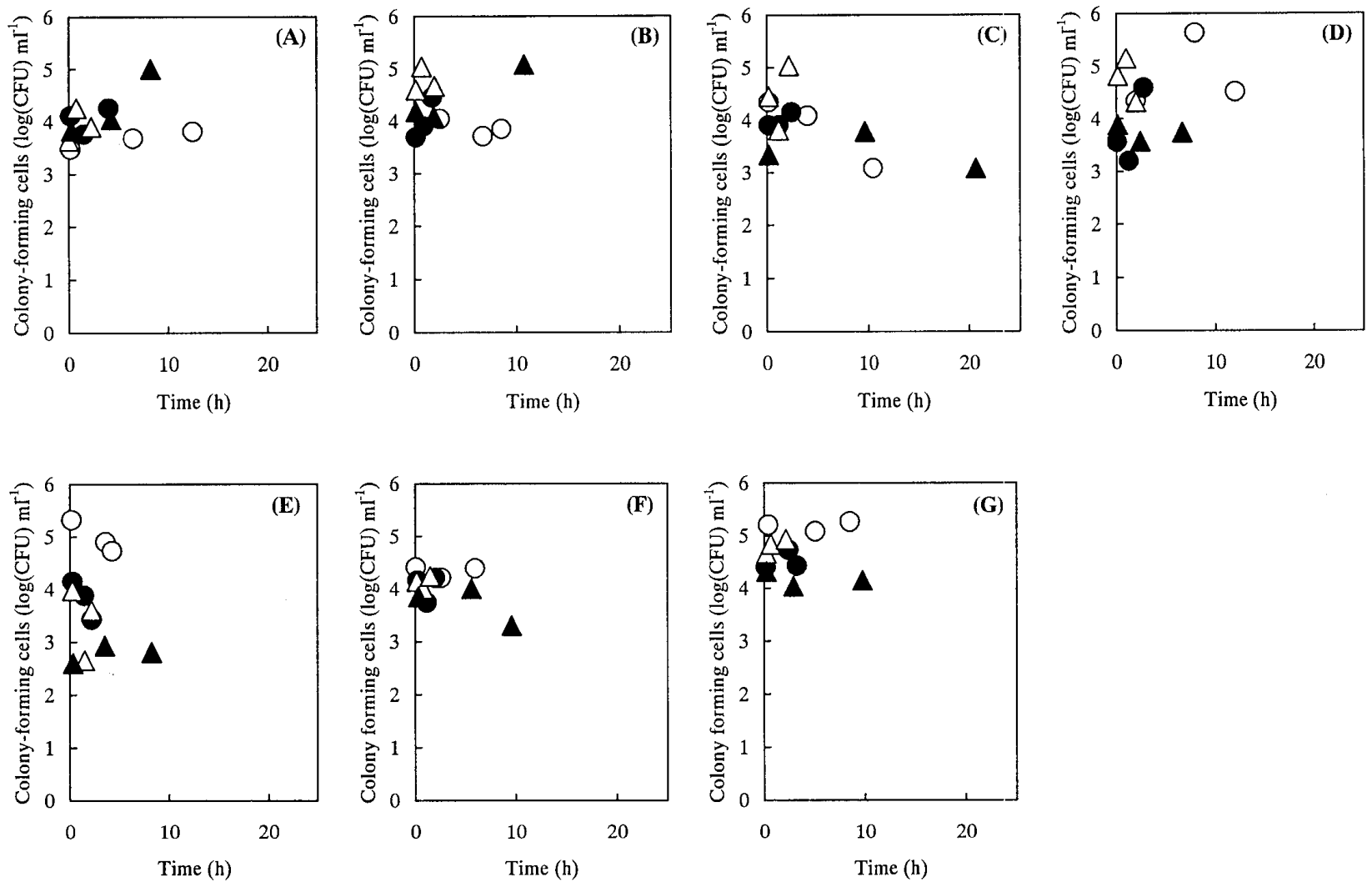

Fig. 4. Changes in the number of colony-forming cells in ballast water while it was loaded on and discharged from the ship. Ballast water was loaded at the Osaka port in January 2005 (A, the first voyage), the Yokkaichi port in April 2005 (B, the second voyage), the Niigata port in September 2005 (C, the third voyage), the Himeji port in October 2005 (D, the fourth voyage), the Osaka port in January 2006 (E, the fifth voyage), the Yokkaichi port in March 2006 (F, the sixth voyage), and the Niigata port in August 2006 (G, the seventh voyage). Ballast water was sampled when it was loaded at a port in Japan (open circle), discharged (closed circle) and re-loaded (open triangle) in the high seas, and discharged from the ship at the Ras Laffan port in Qatar (closed triangle). Enumeration of colony-forming cells in the samples was carried out twice for each sample, and the averaged value is shown here. The difference between the individual and the averaged values was less than 0.2 log cycle for all the samples.

We compared the variation of the number of colony-forming cells in ballast water in relation to the sampling time. For the ballast water taken in Japan, the maximum difference was $10^{1.3} \mathrm{CFU} \mathrm{ml}^{-1}$, which was obtained from the fourth voyage (Fig. 4D). The maximum value of $10^{1.4} \mathrm{CFU} \mathrm{ml}^{-1}$ (Fig. 4D) was obtained from the ballast water samples taken from discharged ballast water in the high seas. While ballast water was re-loaded, the value was $10^{1.3} \mathrm{CFU} \mathrm{ml}{ }^{-1}$ (Fig. 4E). For the samples taken at the Ras Laffan port, the value was $10^{1.2} \mathrm{CFU} \mathrm{ml}^{-1}$ (Fig. 4A).

The number of colony-forming cells varied in ballast water samples when ballast water was taken aboard at the original port and the Indian Ocean as well, indicating that the distribution of marine bacteria in seawater is heterogeneous.

Regardless of the exchange of ballast water in the high seas (Fig. 3 and Table 1), the number of colonyforming cells in ballast water discharged at the Ras
Laffan port varied considerably and remained nearly identical to that in the samples taken in Japan.

In relation to the changes in the number of colony-forming marine bacterial populations, the poor effectiveness for the exchange of ballast water in the high seas was consistent with the results reported by Drake et al ${ }^{(10)}$. However, the exchange of ballast water acts well as for the reduction of the number of planktonic cells in ballast water taken in Japan. In the previous data, about $10^{2}$ planktonic cells in one $\mathrm{ml}$ of the ballast water, which had been taken in spring 2002 in Japan, was reduced to less than one-tenth by the exchange of ballast water in the high seas located in the Indian Ocean $^{(11)}$.

\subsection{Changes in colony-forming marine bacterial populations in ballast water stored in a ballast tank}

In the four ports of call such as Himeji, Osaka, Yok- 
kaichi, and Niigata ports, ballast water was loaded. The pooled ballast water was originated from one of four ports. We believe that the quality of seawater around the coastal area of Japan is roughly the same. Actually, Himeji and Osaka ports are closely located in the Inland Sea. Comparing each data seems to be available primarily.

There were seasonal variations in the number of colony-forming cells in the samples obtained from the pools of ballast water in the ballast tanks (Fig. 5). The numbers of colony-forming cells in the summer samples taken from the surface of the body of water in September 2005 and August 2006, were $10^{4.9}$ and $10^{5.0}$ $\mathrm{CFU} \mathrm{ml}{ }^{-1}$, respectively. On the other hand, the winter sample taken from the surface of the body of water in January 2005 contained $10^{3.3} \mathrm{CFU} \mathrm{ml}{ }^{-1}$. The difference of the values between the surface of the body of water and the middle depth of water taken at the same voyage was within a $10^{0.5} \mathrm{CFU} \mathrm{ml}{ }^{-1}$ for all the samples. Wave action during the voyage might contribute to diffuse marine bacteria within the ballast tanks.

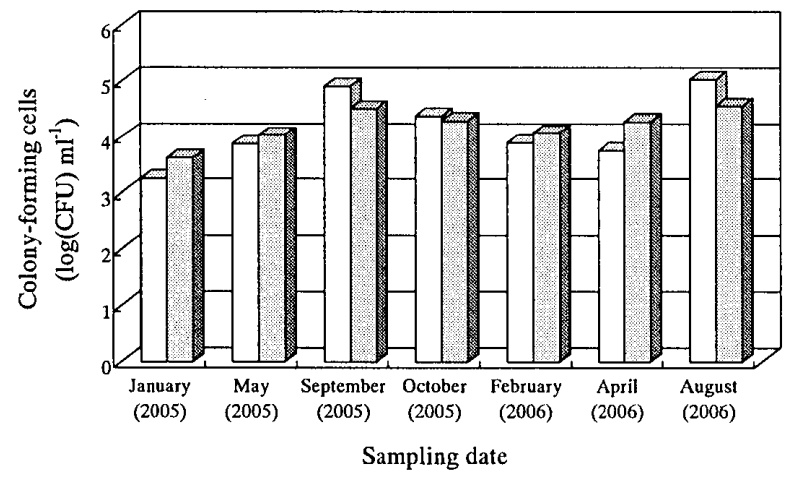

Fig. 5. Seasonal variations in the number of colony-forming cells in the ballast water stored in a ballast tnak. The surface (open column) and a 6-8 m depth water in ballast tank (closed column) were taken from the ballast water stored in a ballast tank. Experiments were carried out twice for each sample, and the averaged value is shown here. The difference between the individual and the averaged values was less than 0.2 $\log$ cycle for all the samples.

\subsection{Total number of colony-forming marine bac- terial populations in sediment in ballast tanks.}

As for the number of colony-forming cells in sediment in the ballast tanks, a 5 - 7 log cycle of the value was estimated on the basis of the water content in the sample (Table 2). The values varied regardless of the season in which the voyage took place. All the values estimated were higher than those obtained from the pools of ballast water in ballast tanks.

Marine bacterial growth in sediment seems to be easier than that in ballast water because dead marine small living things, in general, precipitate on the bottom of ballast tanks, and marine bacteria can utilize some biomaterials composed of the dead cells as nutrients for their growth. Therefore, the sediment management as well as that of ballast water is important ${ }^{(7)}$.

\subsection{Changes in populations of colony-forming marine Vibrio sp. in the ballast water and sedi- ment in ballast tanks}

Total numbers of viable cells, which made colonies on TCBS selective plates at $20^{\circ} \mathrm{C}$, are shown in Table 3. For the numbers of colony-forming marine Vibrio sp. cells in the samples of ballast water, the values varied from $0-2300 \mathrm{CFU} \mathrm{m}{ }^{-1}$ in January to February 2005 (the first voyage), $0-340 \mathrm{CFU} \mathrm{ml}^{-1}$ in April to May 2005 (the second voyage), $0-1980 \mathrm{CFU} \mathrm{ml}^{-1}$ in September to October 2005 (the third voyage), 0-560 $\mathrm{CFU} \mathrm{m}{ }^{-1}$ in October to November 2005 (the fourth voyage), $0-140 \mathrm{CFU} \mathrm{ml}^{-1}$ in January to February 2006 (the fifth voyage), $0-420 \mathrm{CFU} \mathrm{ml}^{-1}$ in March to April 2006 (the sixth voyage), and $0-40 \mathrm{CFU} \mathrm{m}^{-1}$ in August 2006 (the seventh voyage) on the way to Qatar from Japan.

Colony-forming marine Vibrio sp. cells were not detected from the samples taken at re-loading ballast water in the high seas and discharging it at the Ras Laffan port throughout the five voyages out of seven voyages, except for the first and the second voyages. As for the reduction of the number of Vibrio sp. cells in ballast water, the exchange of ballast water seems to work effectively.

As for the samples of sediment taken on the return trip to Japan, the values varied: $0-843 \mathrm{CFU} \mathrm{m}{ }^{-1}$ (the first voyage), $0-8048 \mathrm{CFU} \mathrm{ml}^{-1}$ (the second voyage), 165-331 CFU $\mathrm{ml}^{-1}$ (the third voyage), 0-1831 CFU $\mathrm{ml}^{-1}$ (the fourth voyage), $13275-322708 \mathrm{CFU} \mathrm{ml}^{-1}$ (the fifth voyage), $1750-268215 \mathrm{CFU} \mathrm{ml}^{-1}$ (the sixth voyage), and $0-5866 \mathrm{CFU} \mathrm{ml}^{-1}$ (the seventh voyage).

The populations of the yellow-colored colonies were relatively small in total number of colonies on TCBS selective plate for both samples taken from ballast water and sediment.

\subsection{Effect of storage period of sampled ballast water on the population changes}

The ballast water sample taken aboard at the Himeji port in Japan on October 21, 2005 (the fourth voyage) was used in this experiment. When the sample was arrived in the laboratory, 39 days had already passed 
Table 2. Total number of colony-forming cells in the sediment of ballast tanks.

\begin{tabular}{lll}
$\begin{array}{l}\text { Times of voyages and } \\
\text { sampling date }\end{array}$ & $\begin{array}{l}\text { Colony-forming cells } \\
\left(\log (\mathrm{CFU}) \mathrm{ml}^{-1}\right)^{\mathrm{a}}\end{array}$ & \multicolumn{1}{c}{ Sampling site } \\
\hline 1. February 14, 2005 & $5.2-6.2(5$ samples) & No. 8 ballast tank (port side) \\
2. June 1, 2005 & $5.7-6.1(4$ samples) & No.2 ballast tank (starboard side) \\
3. October 15, 2005 & $5.9-6.5(5$ samples) & No. 9 ballast tank (port side) \\
4. November 16, 2005 & $6.7-7.2(5$ samples) & No.2 ballast tank (starboard side) \\
4. November 17, 2005 & $6.2-6.7(2$ samples) & No.8 ballast tank (starboard side) \\
5. February 21, 2006 & $6.3-6.6(4$ samples) & No. 5 ballast tank (starboard side) \\
5. February 21, 2006 & $5.9-6.6(4$ samples) & No. 6 ballast tank (starboard side) \\
6. April 21, 2006 & $5.7-6.4(3$ samples) & No. 8 ballast tank (starboard side) \\
6. April 21, 2006 & $5.3-5.9(3$ samples) & No. 9 ballast tank (starboard side) \\
7. September 2, 2006 & $6.0-7.0(5$ samples) & No. 4 ballast tank (starboard side) \\
7. September 2, 2006 & $5.6-6.4(4$ samples) & No. 8 ballast tank (starboard side) \\
\hline
\end{tabular}

${ }^{a}$ Sediment was taken from two to five different points in a ballast tank when the ship was carring fully loaded LNG and sailing on the way back to Japan. The sediment $(1 \mathrm{~g})$ was diluted with distilled natural seawater $(9 \mathrm{ml})$. Serial dilution, when necessary, was carried out, and the sample $(0.1 \mathrm{ml})$ was spread onto non-selective agar plates. The number of viable cells were calculated on the basis of the water content of each sample. For example, the viable number of cells, $5.2 \log (\mathrm{CFU}) \mathrm{ml}^{-1}$, obtained from the sample in February 2005, was calculated by the following equation: 107 (number of the colonies on the plate) $\times(9.69 / 0.69) \times(10 / 1) \times$ $(1 / 0.1)=1.5 \times 105 \mathrm{CFU} \mathrm{ml}^{-1}$, where $0.69 \mathrm{ml}$ was the water content in $1 \mathrm{~g}$ of the sample. The minimum and the maximum values are shown here.

since the sample was taken aboard and stored. The number of colony-forming cells in the sample stored for 39 days was $10^{4.3} \mathrm{CFU} \mathrm{ml}^{-1}$ (Fig. 4D and Fig. 6). The change of population in the sample was continuously examined until 117 days since the sample had been stored on board. Total number of colony-forming cells was linearly increased in response to the storage period. Consequently, the value just after the sample was taken aboard was estimated to be $10^{4.0} \mathrm{CFU} \mathrm{ml}{ }^{-1}$ by he extrapolation based on the changes in the numbers of colony-forming cells.

It was found that marine bacterial population gradually increased in the bottle in response to the storage period even when the sample was kept at $4^{\circ} \mathrm{C}$, indicating that the data shown in this paper are maximally two times higher than those just after sampled $\left(10^{4.3} / 10^{4.0}=2\right)$.

\subsection{Identification of isolated Vibrio sp.}

Pathogenic $V$. cholerae can make a yellow-colored colony on TCBS selective agar plate even at $37^{\circ} \mathrm{C}$. Therefore, all the yellow-colored colonies on the TCBS selective agar plates at $20^{\circ} \mathrm{C}$ were picked up and streaked onto new plates, and the colony-forming

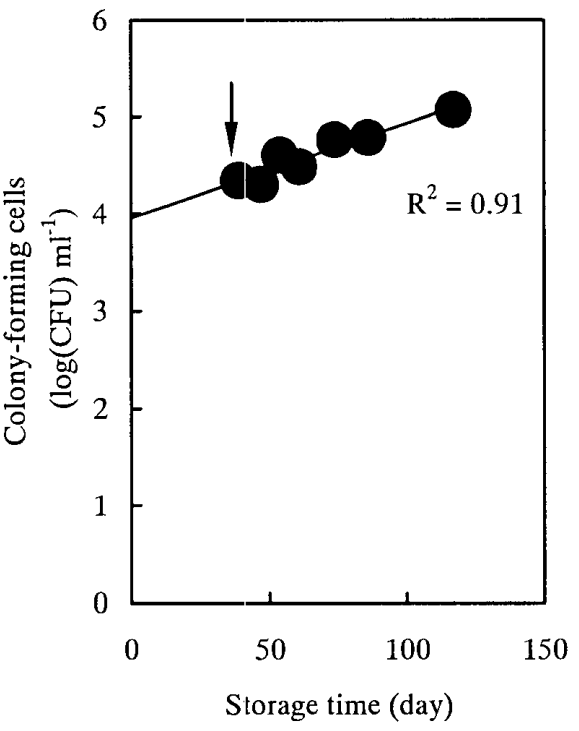

Fig. 6. Change in marine bacterial population in the ballast water sample in response to the days stored. The arrow shows the total days of 39 when the ballast water sample was arrived at the laboratory since the ballast water had been taken aboard at the Himeji port in Japan on October 21, 2005 (the fourth voyage) prior to leaving for Qatar. 
Table 3. Number of colony-forming cells on TCBS selective plates.

Times of voyages Number of colony-forming Sampling time and site and sampling date $\quad$ cells $\left.(\mathrm{CFU} \mathrm{ml})^{-1}\right)^{\mathrm{a}}$

1. January $16,2005 \quad 0-1400(0)$

1. January $25,2005 \quad 40-70(0-10)$

1. January $25,2005 \quad 50-70(10-30)$

1. January $26,2005 \quad 0-20(0)$

1. January $26,2005 \quad 250-970(10-50)$

1. February $1,2005 \quad 100-2300(0-200)$

1. February 14, $2005 \quad 0-843(0)$

2. April 24, $2005 \quad 0-40(0-20)$

2. May $5,2005 \quad 270-340(270-340)$

2. May $5,2005 \quad 20-40(0-10)$

2. May 7, $2005 \quad 0-30(0)$

2. May 7, $2005 \quad 0-20(0)$

2. May $21,2005 \quad 0-180(0)$

2. June $1,2005 \quad 0-8048(0-7512)$

3. September 17, $200560-1980(0-60)$

3. September 26, 20050

3. September 26, 20050

3. September 27, 20050

3. September 27, 20050

3. October $5,2005 \quad 0$

3. October 15, $2005 \quad 165-331(0-165)^{\mathrm{b}}$

4. October 21, $2005 \quad 0-560(0)$

4. October 30, $2005 \quad 0-10(0)$

4. October 30, $2005 \quad 0$

4. October 31, $2005 \quad 0$

4. November 1, $2005 \quad 0$

4. November 10, 20050

4. November 16, $20050-432(0-168)^{c}$

4. November 17, 20050 - $1831(0-1549)$

5. January $28,2006 \quad 0$

5. February 5, $2006 \quad 40-140(10-30)$

5. February 5, $2006 \quad 40-90(0)$

5. February 5, $2006 \quad 0$

5. February 5, $2006 \quad 0$

5. February 11, $2006 \quad 0$

5. February 21, $2006 \quad 13275-322708$

(129 - 1952)

5. February 21, $2006 \quad 30057-49506$

$(0-1559)$
While loading at the Osaka port in Japan

Surface of ballast water

$7 \mathrm{~m}$ depth of ballast water

While discharging in the high seas

While reloading in the high seas

While discharging at the Ras Laffan port in Qatar

Sediment in No. 8 side tank at the port side

While loading at the Yokkaichi port in Japan

Surface of ballast water

$7 \mathrm{~m}$ depth of ballast water

While discharging in the high seas

While reloading in the high seas

While discharging at the Ras Laffan port in Qatar

Sediment in No. 2 side tank at the starboard side

While loading at the Niigata port in Japan

Surface of ballast water

$6 \mathrm{~m}$ depth of ballast water

While discharging in the high seas

While reloading in the high seas

While discharging at the Ras Laffan port in Qatar

Sediment in No. 9 side tank at the port side

While loading at the Himeji port in Japan

Surface of ballast water

$8 \mathrm{~m}$ depth of ballast water

While discharging in the high seas

While reloading in the high seas

While discharging at the Ras Laffan port in Qatar

Sediment in No. 2 side tank at the starboard side

Sediment in No. 8 side tank at the starboard side

While loading at the Osaka port in Japan

Surface of ballast water

$7 \mathrm{~m}$ depth of ballast water

While discharging in the high seas

While reloading in the high seas

While discharging at the Ras Laffan port in Qatar

Sediment in No. 5 side tank at the starboard side

Sediment in No. 6 side tank at the starboard side 
6. March 31, $2006 \quad 0$

6. April 9, 2006

410 - $420(50$ - 110)

6. April 9, 2006

$70-90(0)$

6. April 10, 2006

0

6. April 10, 2006

0

6. April 16, 2006

0

6. April 21, 2006

$1750-5531$

$(1750$ - 5531)

6. April 21, 2006

$160040-268215$

$(1482-9085)^{d}$

7. August 6, 2006

0

7. August 15, 2006

7. August 15, 2006

7. August 17, 2006

7. August 17, 2006

7. August 23, 2006

7. September 2, 2006

7. September 2, 2006
While loading at the Yokkaichi port in Japan

Surface of ballast water

$8 \mathrm{~m}$ depth of ballast water

While discharging in the high seas

While reloading in the high seas

While discharging at the Ras Laffan port in Qatar

Sediment in No. 8 side tank at the starboard side

Sediment in No. 9 side tank at the starboard side

While loading at the Niigata port in Japan

Surface of ballast water

$7 \mathrm{~m}$ depth of ballast water

While discharging in the high seas

While reloading in the high seas

While discharging at the Ras Laffan port in Qatar

Sediment in No. 4 side tank at the starboard side

Sediment in No. 8 side tank at the starboard side

\footnotetext{
${ }^{\mathrm{a}}$ TCBS selective plates were kept at $20^{\circ} \mathrm{C}$ for two days. Then total number of colonies on the plates were counted. For seawater samples, they were taken one to three times at given sampling time in a sampling site, and each sample was spread twice onto TCBS selective plates. The minimum and the maximum numbers of colonies are shown here. For sediment samples, which were taken from two to five different sampling points in a ballast tank, each sample of sediment $(1 \mathrm{~g})$ was diluted with autoclaved natural sea water $(9 \mathrm{ml})$, and an aliquot $(0.1 \mathrm{ml})$ was spread onto TCBS selective plates. For example, the viable number of cells, $843 \mathrm{ml}^{-1}$, obtained from the sample in February 2005, was calculated by the following equation:

6 (number of the colonies on the plate) $\times(9.69 / 0.69) \times(1 / 0.1)=843 \mathrm{CUF} \mathrm{ml}^{-1}$, where $0.69 \mathrm{ml}$ was the water content in $1 \mathrm{~g}$ of the sample. The minimum and the maximum numbers of colonies in sediment samples taken from a ballast tank are shown here. In parentheses, the minimum and the maximum values for yellow-colored colonies grown at $20^{\circ} \mathrm{C}$ were shown.

${ }^{\mathrm{b}}$ One strain, which made a yellow-colored colony at $20^{\circ} \mathrm{C}$ on the TCBS selective plate, could grow at $37^{\circ} \mathrm{C}$. The isolate was named as SB0307.

${ }^{c}$ One strain, which made a yellow-colored colony at $20^{\circ} \mathrm{C}$ on the TCBS selective plate, could grow at $37^{\circ} \mathrm{C}$. The isolate was named as SB0407.

${ }^{\mathrm{d}}$ Total five strains, which made yellow-colored colonies at $20^{\circ} \mathrm{C}$, could grow at $37^{\circ} \mathrm{C}$. One of those strains grew even at $45^{\circ} \mathrm{C}$. The isolate was named as SB0610. For remaining 4 colonies, we named as SB0611, SB0612, SB0613, and SB0614.

${ }^{\mathrm{e}}$ Two strains, SB0708 and SB0709, made yellow-colored colonies at $20^{\circ} \mathrm{C}$ on the TCBS selective plate, and could grow even at $37^{\circ} \mathrm{C}$.
}

ability was checked at $37^{\circ} \mathrm{C}$. As a result, we obtained seven isolates. They were identified based on the biochemical, physiological, and partial 16S rDNA sequences (Table 4). The partial 16S rDNA sequence of the isolate SB0307 showed a high homology percentage of more than $99 \%$ to that of the type culture of $V$. alginolyticus (ATCC 17749) (99.6\%), V. parahaemolyticus (ATCC17802) (99.6\%), and $V$. campbellii (ATCC 25920) (99.6\%), when homology analysis was carried out by using the database of GenBank/DDBJ/ EMBL. According to the molecular phylogenetic tree made by the neighbor-joining method, the isolate 
SB0307 was gathered the same phylogenetic branch with $V$. alginolyticus (ATCC 17749) and V. parahaemolyticus (ATCC 17802), where the bootstrap values for $V$. alginolyticus (ATCC 17749) and $V$. parahaemolyticus (ATCC 17802) were the same as $59 \%$. Since $V$. parahaemolyticus is not able to produce acid metabolites from sucrose, the color of colonies made on TCBS selective agar plate shows green. Consequently, the isolate SB0307 was identified to be $V$. alginolyticus.

As for the isolate SB0407, the partial sequence of 16S rDNA showed a highly homologous percentage of $95.6 \%$ to the type culture of Photobacterium damselae subsp. damselae (ATCC 33539). In general, the identification of species seems to be difficult when the homologous percentage in database is less than $97 \%$, indicating that the isolate is a novel strain. The partial rDNA sequence of the isolate, SB0407, was deposited in the $\mathrm{DDBJ} / \mathrm{GenBank} / \mathrm{EMBL}$ under the accession number AB274303.

The isolate SB0610 showed $99.3 \%$ of sequence homology with $V$. alginolyticus (ATCC 17749) in database of GeneBank/DDBJ/EMBL. In the molecular phylogenetic tree, the isolate SB0307 was gathered the same phylogenetic branch with $V$. alginolyticus (ATCC 17749) and $V$. parahaemolyticus (ATCC 17802), where the bootstrap values for $V$. alginolyticus (ATCC 17749) and $V$. parahaemolyticus (ATCC 17802) were 48 and $39 \%$, respectively. As described above, the color of colony for $V$. parahaemolyticus on
TCBS selective agar plate is green, so that the isolate SB0307 was identified to be $V$. alginolyticus.

All of the isolates, SB0611, SB0612, SB0613, SB0611, SB0708, and SB0709, were identified to be $V$. harveyi. The homologous percentage of the partial rDNA sequence for each isolate was $99.4 \%$ to V. harveyi (ATCC 35084) in the database of GenBank/DDBJ/EMBL, and the bootstrap value in the phylogenetic branch was to be $91 \%$.

Pathogenic $V$. cholerae invaded into ballast water and sediment in ballast tanks is a major concern for public health of the people who are living around the coastal area ${ }^{(12)}$. Pathogenic $V$. cholerae 01 can survive in seawater more than 50 days ${ }^{(13)}$. Therefore, regulations adopted by IMO in 2004 placed restrictions on acceptable microbial populations in ballast water as human standard ${ }^{(14)}$. In the regulations, $V$. cholerae $\mathrm{O} 1$ and $\mathrm{O} 139$ were limited to less than one CFU $100 \mathrm{ml}^{-1}$ or less than one CFU (gram (wet weight) zooplankton sample) ${ }^{-1}$.

We should use more than $100 \mathrm{ml}$ of ballast water samples in order to try to detect pathogenic $V$. cholerae because the minimum unit proposed by IMO was $100 \mathrm{ml}$. In the experiments, we just spread $100 \mu \mathrm{l}$ of each sample onto TCBS agar plates $(n=2)$. This experimental protocol might not be suitable for the complete detection of pathogenic $V$. cholerae in the ship's ballast water and sediment, although it is obviously impossible to examine total volume of ballast water and sediment in ballast tanks.

Table 4. Identification of yellow-colored colonies made on TCBS selective plate at $37^{\circ} \mathrm{C}$.

\begin{tabular}{|c|c|c|c|}
\hline Sampling date & Sampling site & Strain & Identification $^{\mathrm{a}}$ \\
\hline October 15,2005 & Sediment & SB0307 & Vibrio alginolyticus $(99.6 \%)^{b}$ \\
\hline November 16,2005 & Sediment & SB0407 & Photobacterium damselae $(95.7 \%)^{\mathrm{b}}$ \\
\hline \multirow[t]{2}{*}{ April 21, 2006} & Sediment & SB0610 & Vibrio alginolyticus $(99.3 \%)^{\mathrm{b}}$ \\
\hline & Sediment & $\begin{array}{l}\text { SB0611, SB0612, } \\
\text { SB0613, SB0614 }\end{array}$ & Vibrio harveyi $(99.4 \%)^{\mathrm{b}, \mathrm{d}}$ \\
\hline September 2, 2006 & Sediment & SB0708, SB0709 & Vibrio harveyi $(99.3 \%)^{\mathrm{b}, \mathrm{e}}$ \\
\hline
\end{tabular}

${ }^{a}$ Identification was carried out based on the partial rDNA sequence (about $500 \mathrm{bp}$ ) as well as the biochemical and physiological properties.

${ }^{b}$ Homologous percentage obtained from the homology analysis using the data base of GenBank/DDBJ/EMBL is shown in parentheses.

${ }^{c}$ In general, identification based on 16S rDNA requires the homologous percentage of more than $97.0 \%$ in the database. Therefore, the sequence was deposited in GenBank/DDBJ/EMBL, and the isolate was listed as a newly isolated Photobacterium sp. SB0407. Accession number is AB274303.

${ }^{\mathrm{d}}$ The data of the sequence and the homologous percentage obtained from each isolate were the same as those of other three isolates.

${ }^{\mathrm{e}}$ The data of the sequence and the homologous percentage obtained from two isolates were quite the same. 


\section{Conclusions}

Japan imports large amounts of crude oil and LNG from the Middle East, and very large crude oil carriers and LNG carriers sailing from Japan to the countries export ballast water, the amount of which is about a half to almost the equal of the fully loaded cargos of crude oil or LNG. Therefore, investigation for detecting pathogenic $V$. cholerae in the ports and along the coastal area of Japan is very important. Fifty-one $V$. cholerae $\mathrm{O} 1$ strains, which were identified to be $\mathrm{El}$ Tor biotype, Ogawa serotype, have been isolated in a port of Osaka, Japan in 1987 to $2001^{(15)}$. All of the isolates were cholera toxin (CT) negative and CT gene negative. Continuous investigations should be carried out to ensure that coastal seawater is not polluted by pathogenic $V$. cholerae.

The convenient detection and pasteurization technologies, which are rather than time consuming and available to use on board, are required for the management of ships' ballast water and sediment in ballast tanks.

\section{Acknowledgements}

This work was partially supported by a Grant-in Aid for Scientific Research (B), JSPS, Japan Science Promotion Society, as No. 16360437 . We appreciate the contribution of the officers and crew of the LNG Carrier, ZEKREET, KAWASAKI KISEN KAISHA, LTD., for taking all the samples on board.

\section{References}

(1) G. M. Ruiz, T. K. Rawlings, F. C. Dobbs, L. A. Drake, T. Mullady, A. Huq, and R. R. Colwell: Global spread of microorganisms by ships, Nature, vol. 408, pp. 49-50, 2000.

(2) G. M. Hallegraeff and C. J. Bolch: Transport of toxic dinoflagellate cysts via ships' ballast water, Mar. Pollut. Bull., vol. 22, pp. 27-30, 1991.

(3) G. M. Hallegraeff and C. J. Bolch: Transport of diatom and dinoflagellate resting spores in ships' ballast water: Implications for plankton biogeography and aquaculture, J. Plankton Res., vol. 14, pp. 1067-1084, 1992.

(4) G. M. Hallegraeff: Transport of toxic dinoflagellates via ships' ballast water: Bioeconomic risk assessment and efficacy of possible ballast water management strategies, Mar. Ecol.
Prog. Ser., vol. 168, pp. 297-309, 1998.

(5) International Maritime Organization: Alien invaders-putting a stop to the ballast water hitch-hikers, Available from

http://www.imo.org/includes/blastDataOnly.asp/data i $\mathrm{d}=6006 /$ Ballastinvaders.pdf.

(6) P. Ambros: US legislate to prevent zebra mussel spread, Mar. Pollut. Bull., vol. 32, pp. 765-766, 1996.

(7) H. Mimura, R. Katakura, and H. Ishida: Changes of microbial populations in a ship's ballast water and sediments on a voyage from Japan to Qatar, Mar. Pollut. Bull., vol. 50, pp. 751-757, 2005.

(8) L. A. Drake, M. A. Doblin, and F. C. Dobbs: Potential microbial bioinvasions via ship's ballast water, sediment, and biofilm, Mar. Pollut. Bull., vol. 55, pp. 333-341, 2007.

(9) International Maritime Organization, International convention for the control and management of ship's ballast water and sediments. Available from http://www.imo.org/Conventions/mainframe.asp?t opic id=867. 2004.

(10) L. A. Drake, G. M. Ruiz, B. S. Galil, T. L. Mullady, D. O. Friedmann, and F. C. Dobbs: Microbial ecology of ballast water during a transoceanic voyage and the effects of open-ocean exchange, Mar. Ecol. Prog. Ser., vol. 233, pp. 13-20, 2002.

(11) K. Kozai, H. Ishida, K. Okamoto, and Y. Fukuyo: Feasibility study of ocean color remote sensing for detecting ballast water, Adv. space res., vol. 37, pp. 787-792, 2006.

(12) V. R. Louis, E. R-Cohen, N. Choopun, I. N. G. Rivera, B. Gangle, S. C. Jiang, A. Rubin, J. A. Patz, A. Huq, and R. R. Colwell: Predictability of Vibrio cholerae in Chesapeake Bay, Appl. Environ. Microbiol., vol. 69, pp. 2773-2785, 2003.

(13) P. M. Munro and R. R. Colwell: Fate of Vibrio cholerae $\mathrm{O} 1$ in seawater microcosms, Wat. Res., vol. 30, pp. 47-50, 1996.

(14) International Maritime Organization, International Convention for the Control and Management of Ships' Ballast Water and Sediments adopted in 2004, at http://www.imo.org/home.asp .

(15) K. Miyagi, T. Nakano, T. Yagi, M. Hanafusa, S. Imura, T. Honda, Y. Nakano, and K. Sano: Survey of Vibrio cholerae $\mathrm{O} 1$ and its survival over the winter in marine water of Port of Osaka, Epidemiol. Infect., vol. 131, pp. 613-619, 2003. 


\section{Questions and Answers}

\section{Shinya Yukihira (Kyushu University)}

You have emphasized the importance of the management of sediment in ballast tanks as well as ballast water prior to discharging ballast water from the vessel. Actually, how should ballast water and sediment be managed?

\section{Shuhei Okuyama}

Ballast water pooled in ballast tanks is necessary to be treated completely having no living things prior to discharging from vessels. The prevention of outflow of untreated sediment also requires on the voyage.

\section{Masanori Tsugane (Tokai University)}

Although you mentioned that the seasonal changes in colony-forming marine bacterial populations were observed in the pooled ballast water samples which had been taken in Japan throughout seven voyages, ports of call in Japan varied in your experiments. What do you think about the influence of the different sampling sites in Japan on the seasonal changes of the number of colony-forming cells in the pooled ballast water?

Why was not the number of colony-forming cells in the ballast water samples taken in Japan reduced even when the ballast water was exchanged in the Indian Ocean?

\section{Shuhei Okuyama}

As you pointed out, ballastwater was loaded at four different ports such as Himeji, Osaka, Yokkaichi, and Niigata ports in the seven voyages. We believe that the quality of seawater around the coastal area of Japan is roughly the same. Actually, Himeji and Osaka ports are closely located in the Inland Sea. Comparing each data seems to be available primarily.

In general, marine bacteria can survive several weeks in dark and cool environments. That is why the obvious reduction of the number of colony-forming marine bacterial populations was not observed at the ballast water exchange site in the Indian Ocean. 